\title{
RNA:DNA ratios of calanoid copepods from the epipelagic through abyssopelagic zones of the North Pacific Ocean
}

\author{
Tsutomu Ikeda*, Fumikazu Sano, Atsushi Yamaguchi, Takashi Matsuishi
}

Graduate School of Fisheries Sciences, Hokkaido University, Minato-machi, Hakodate 041-0921, Japan

\begin{abstract}
As indices of protein synthetic activity, RNA:DNA ratios were determined for $>80$ copepod species caught from the epipelagic (0 to $500 \mathrm{~m}$ ), mesopelagic (500 to $1000 \mathrm{~m})$, upper bathypelagic (1000 to $2000 \mathrm{~m})$, lower bathypelagic (2000 to $3000 \mathrm{~m}$ ) and abyssopelagic (3000 to $5000 \mathrm{~m}$ ) zones of the North Pacific Ocean. The copepods from the epipelagic zone exhibited higher RNA:DNA ratios compared to those from the mesopelagic through the abyssopelagic zones. Parameters (other than the depth zones) affecting the ratios were explored, by grouping the copepods into 4 developmentalstage/sex categories (C4, C5 and C6 females and males), 3 feeding types (carnivore, detritivore and suspension feeder), or 2 phylogeny-related reaction-speed groups in which detecting the presence or absence of myelinated sheath enveloping axons indicated fast or slow reacting species, respectively. Stage and sex data showed that RNA:DNA ratios were greater in C6 females than in other groups. Among the feeding-type data, carnivores exhibited the lowest RNA:DNA values. Reaction-speed data indicated that slow-reacting species are characterized by lower ratios than fast-reacting species. Taking into account all of these biological parameters as independent variables, stepwise multiple regression analysis revealed that the pattern of the reduction in RNA:DNA ratios toward greater depths was still valid. The typical interzonal copepods, Neocalanus spp., showed that non-feeding C6 females of $N$. plumchrus and $N$. flemingeri collected from the mesopelagic through the abyssopelagic zones had high RNA:DNA ratios comparable to those of the epipelagic-zone copepods. The present results, combined with recent reports on the depth-related decline in the metabolism and body nitrogen content of pelagic copepods downward, suggest overall slower life modes of deeper-living species. We think the 'predation-mediated selection' hypothesis explains this 'slow' life more effectively than limited food supply or colder temperatures in the deep sea.
\end{abstract}

KEY WORDS: Copepods · RNA · DNA · Abyssopelagic $\cdot$ North Pacific

\section{INTRODUCTION}

Copepods are the major component of the mesozooplankton in the ocean and are considered to be vital agents in biogeochemical cycles of carbon and other elements in the pelagic ecosystems (Hernández-León \& Ikeda 2005, Buitenhuis et al. 2006). Based on voluminous experimental data accumulated on epipelagic copepods, their physiological processes - including metabolism (Ikeda et al. 2001), growth (Hirst \& Bunker 2003) and mortality (Hirst \& Kiørboe 2002) - have been modeled as a function of body mass and habitat temperature. With a notable exception of a globalbathymetric model developed for respiration of pelagic copepods (Ikeda et al. 2007), the validity of the models to deep-sea copepods is uncertain at present, because of the very limited understanding of their physiological characteristics.

Since RNA is a necessary precursor of protein synthesis and protein is usually the major body component, early attempts have been made to establish the relationship between RNA content and growth rate in 
copepods and mixed zooplankton taxa (Dagg \& Littlepage 1972, Båmstedt \& Skjoldal 1980, Båmstedt 1983, Ota \& Landry 1984). In earlier studies, RNA contents were normalized by dry weight (DW) of the samples; however, recent studies have used DNA instead of DW, because the amount of DNA is stable per nucleus or per cell. The advent of fluorophores such as ethidium bromide (EB) in RNA and DNA assays, adapted to a microplate technique (Wagner et al. 1998), has enabled analysis of individual copepods (as compared with the pooling of several specimens to reach the $>0.8 \mathrm{mg}$ DW per assay necessary in the conventional UV absorption techniques of early studies; cf. Canino \& Caldarone 1995).

Recent studies on individual copepods such as Calanus finmarchicus (Wagner et al. 1998, 2001), Acartia grani (Saiz et al. 1998) and A. bifilosa (Gorokhova 2003) have successfully established the relationships between RNA:DNA ratios and protein synthetic activities (determined as somatic growth or egg production rates) as influenced by temperature and food level. Nevertheless, because of the high species diversity of marine calanoid copepods (1800 species; Mauchline 1998), it is difficult to draw conclusions on species-specific differences from the limited number of copepod species on which RNA:DNA ratios have been analyzed to date $(<10$ species). Aside from copepods, RNA:DNA ratios have been shown to be a good index for diagnosis of nutritional conditions and recent growth (all related to protein synthetic activities) of various fish larvae (Caldarone et al. 2001, Malzahn et al. 2003), cladocerans (Gorokhova \& Kyle 2002), euphausiids (Shin et al. 2003) and cephalopods (Clarke et al. 1989).

As part of our research program on depth-related patterns of marine zooplankton, we have already demonstrated that deeper-living calanoid copepods are characterized by their low metabolic rate and nitrogen content (Ikeda et al. 2006a,b). On the ground that protein synthesis has the highest energy demand among the processes involved in the formation of new body mass in copepods (Kiørboe et al. 1985, Thor 2000), reduced metabolic rates of deep-sea copepods suggest lower protein synthetic activities (or slower protein growth rates). Unfortunately, no information is presently available about growth conditions of deep-sea calanoid copepods. In this study we determined RNA:DNA ratios of copepods inhabiting the epipelagic through abyssopelagic zones in the North Pacific Ocean to examine depth-related patterns. To achieve the objective, the possible effects of other parameters (developmental-stage/sex, food habits, and phylogeny-based reaction speed against predators' stimuli) on their RNA:DNA ratios were analyzed simultaneously to achieve better resolution of the effect of the depth of occurrence.

\section{MATERIALS AND METHODS}

Samples. Copepod specimens were collected at a total of 22 stations in the North Pacific and 2 stations in the Bering Sea during the TS (training ship) 'OshoroMaru' Cruises 135 (May), 137 (June to August) and 142A (December) in 2003; 143B (February) in 2004; and during the RV 'Tansei-Maru' Cruise KT-04-18 in August 2004 (Fig. 1). Most deep samplings were made at Stns 3 (Site H) and 5 (Stn Knot) in the western North Pacific. A vertical closing net (Kawamura 1968; dimensions modified: diameter $80 \mathrm{~cm}$, mesh size $0.3 \mathrm{~mm}$ ) equipped with a large cod-end (1 to 21 capacity) was used to collect zooplankton from the epipelagic $(0$ to $500 \mathrm{~m})$, mesopelagic $(500$ to $1000 \mathrm{~m})$, upper bathypelagic (1000 to $2000 \mathrm{~m}$ ), lower bathypelagic (2000 to $3000 \mathrm{~m}$ ) and abyssopelagic zones (3000 to $5000 \mathrm{~m}$ ). The net was towed from the bottom to the top of a designated depth stratum at a speed of $1 \mathrm{~m} \mathrm{~s}^{-1}$, closed and subsequently brought to the surface at $2 \mathrm{~m} \mathrm{~s}^{-1}$. An RMD depth meter (Rigosha), attached to the suspending cable of the net, was used to measure net depth. A closing cod-end was developed (T. Ikeda unpubl.) to maintain near in situ temperature of the zooplankton samples during net retrieval; this was

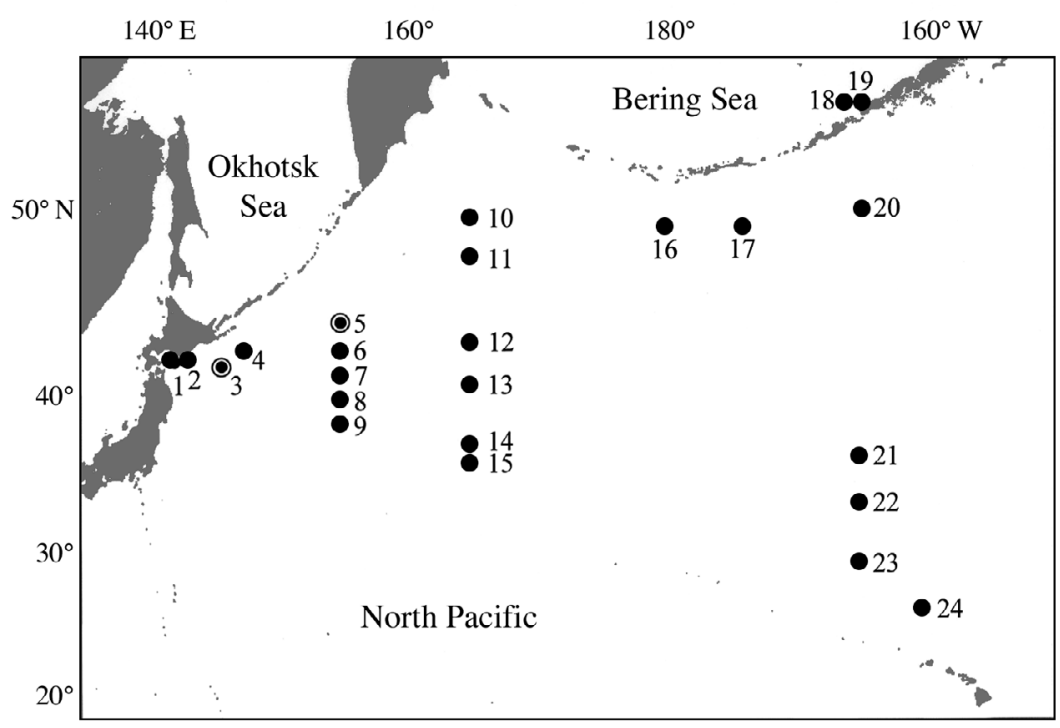

Fig. 1. Sampling stations (๑) (deep samplings: $\bigcirc)$ in the North Pacific Ocean and Bering Sea. Stn 3: Site Hi Stn 5: Stn Knot 
used when the water temperature at the surface layer exceeded $10^{\circ} \mathrm{C}$. Upon retrieval of the net, undamaged specimens of copepods were sorted immediately. Individual specimens were observed quickly under a dissecting microscope to determine species, developmental stage and sex. Each specimen was then preserved separately in liquid nitrogen and brought back to the land laboratory for nucleic acid analysis.

Nucleic acid analysis. RNA and DNA were measured with the microplate fluorescent assay (MFA) of Wagner et al. (1998). The MFA assay is a modification of the sequential fluorometric method of Bentle et al. (1981), in which DNA and RNA in a single sample are determined sequentially by the addition of DNase and RNase using EB as fluorescent dye (see Caldarone et al. 2001 for details). Wagner et al. (1998) modified the sequential fluorometric method to the MFA with 96-well microtiter plates by adopting a sarcosyl extraction technique and eliminating the DNase step, thus allowing application of the assay to small samples (single copepods) without extended working time.

Prior to the assay, the wet weight (WW) of individual specimens (preserved in liquid nitrogen) was determined; these specimens were then homogenized by vigorous shaking with sarcosyl extraction buffer. For some specimens weighing $<0.5 \mathrm{mg} W \mathrm{~W}$, a batch of 2 to 3 specimens was used. The volume of extraction buffer was $200 \mu \mathrm{l}$ for specimens weighing $<1.5 \mathrm{mg}$, $500 \mu \mathrm{l}$ for those 1.5 to $5 \mathrm{mg}, 1000 \mu \mathrm{l}$ for those 5 to $10 \mathrm{mg}$ and $2000 \mu \mathrm{l}$ for those $>10 \mathrm{mg} \mathrm{WW}$. The samples were shaken for $1 \mathrm{~h}$ at room temperature on a vortex mixer equipped with a multiple-vial head. The samples were then diluted 1:4 with Tris buffer to reduce the sarcosyl concentration to $0.2 \%$, and were shaken again for $5 \mathrm{~min}$. They were then centrifuged $(12000 \times g)$ for $10 \mathrm{~min}$ to separate insoluble copepod remains.

In each run, duplicate $75 \mu \mathrm{l}$ aliquots of supernatants of the samples and 8 replicates of $0,2.0$ and $7.6 \mu \mathrm{g} \mathrm{ml}^{-1}$ DNA (calf-thymus, Sigma D-3664 or D-4522) and 0, 1.5 and $11.0 \mu \mathrm{g} \mathrm{ml}^{-1}$ RNA standard solutions (calf-liver, 18S + 28S ribosomal RNA, Sigma R-0889) were transferred to 96-well microplates (Corning-Black). The zero concentrations of the standard solutions can also be regarded as reagent blanks (containing all chemicals but no copepod homogenates). The 2 concentrations of DNA and RNA were chosen because the fluorescence has been shown to be linear within these ranges (see below, this section). EB solution (75 $\mu$ l) was added to each well, and the plates were shaken gently at room temperature for $15 \mathrm{~min}$. The EB fluorescence was then scanned on a microplate reader (GENios, TECAN) with $530 \mathrm{~nm}$ (excitation) and $590 \mathrm{~nm}$ (emission) filters (first scan). Gain-sensitivity was set to 120, and flash-replicate measuring to 10. Following the first scan, RNase solution $(7.5 \mu \mathrm{l})$ was added to each well.
The microplate was shaken again at room temperature for $20 \mathrm{~min}$ and the EB fluorescence was scanned (second scan). The RNA concentrations $\left(\mu \mathrm{g} \mathrm{ml}^{-1}\right)$ were calculated as the differences between the first (DNA+ RNA) and the second (DNA) scans, and the standard curve of RNA versus the fluorescence established from the first scan of the same plate. DNA concentrations $\left(\mu \mathrm{g} \mathrm{ml}^{-1}\right)$ were computed from the second scan and the standard curve of DNA versus fluorescence established at the second scan (RNase treated) of the same plate.

We confirmed linear fluorescence-concentration relationships by using 5 dilution series of DNA ranging from 0.0 to $7.6 \mathrm{ug} \mathrm{ml}^{-1}\left(y=963.2 x+3034, \mathrm{r}^{2}=0.997\right)$ and RNA ranging from 0.0 to $11.3 \mu \mathrm{g} \mathrm{ml}^{-1}(y=574.8 x+$ 2967, $\mathrm{r}^{2}=0.999$ ). Coefficients of variations (CV: SD $\times 100 /$ mean), derived from repeated measurements of the same concentrations of DNA and RNA standards, were approximately $2 \%$. Well-to-well variabilities in the fluorescence, as tested on the same standard concentrations of DNA and RNA, were 2 to $3 \%(C V, n=4)$. Day-to-day variations (CVs) in reagent blanks, and the slopes of the DNA and RNA standard curves were 11, 6 and $11 \%$, respectively, over a little less than 6 mo of our analysis. Known amounts of DNA $(0.142 \mu \mathrm{g})$ and RNA $(0.226 \mu \mathrm{g})$ were spiked to part of samples and resultant recoveries were $100 \%( \pm 7.2 \%, \mathrm{n}=8)$ and $101 \%( \pm 9.9 \%, \mathrm{n}=8)$, respectively, with the present assay procedure. Accordingly, no correction for the recovery efficiency was made for the present results.

To define the body mass of each copepod accurately, part of its homogenate $(250 \mu \mathrm{l})$ was used for protein determinations in duplicate according to the method of Lowry et al. (1951), using bovine serum albumin as a standard.

\section{RESULTS \\ Copepods}

Calanoid copepod species belonging to the 6 Superfamilies (Arietelloidea, Centropagoidea, Clausocalanoidea, Eucalanidea, Megacalanoidea, and Spinocalanoidea) and 14 Families (Augaptilidae, Hetrorhabdidae, Lucicutiidae, Metridinidae, Arietellidae, Candaciidae, Aetideidae, Euchaetidae, Phaennidae, Scolecitrichidae, Eucalanidae, Calanidae, Megacalanidae and Spinocalanidae) were used for the analyses (Table 1, Appendix 1 available as Supplementary Material at www.int-res.com/articles/suppl/b001p099_ app.pdf). Interzonal copepods, Neocalanus cristatus, $N$. plumchrus and $N$. flemingeri, are of special interest in the subarctic North Pacific because of their dominance in copepod communities in the water column 
Table 1. Copepod Superfamilies, Families and genera analysed in the present study

\begin{tabular}{|c|c|c|}
\hline Superfamily & Family & Genus \\
\hline Arietelloidea & $\begin{array}{l}\text { Augaptilidae } \\
\text { Heterorhabdidae } \\
\text { Lucicutiidae } \\
\text { Metridinidae }\end{array}$ & $\begin{array}{l}\text { Euaugaptilus } \\
\text { Neoaugaptilus } \\
\text { Heterorhabdus } \\
\text { Heterostylites } \\
\text { Lucicutia } \\
\text { Metridia } \\
\text { Pleuromamma }\end{array}$ \\
\hline Centropagoidea & Candaciidae & Candacia \\
\hline Clausocalanoidea & $\begin{array}{l}\text { Euchaetidae } \\
\text { Phaennidae } \\
\text { Scolecitrichidae }\end{array}$ & $\begin{array}{l}\text { Aetideopsis } \\
\text { Bradyidius } \\
\text { Chiridius } \\
\text { Euchirella } \\
\text { Gaetanus } \\
\text { Gaidius } \\
\text { Pseudochirella } \\
\text { Pseudogaetanus } \\
\text { Undeuchaeta } \\
\text { Euchaeta } \\
\text { Paraeuchaeta } \\
\text { Cornucalanus } \\
\text { Onchocalanus } \\
\text { Amallothrix } \\
\text { Racovitzanus } \\
\text { Scaphocalanus } \\
\text { Scolecithricella }\end{array}$ \\
\hline Eucalanoidea & Eucalanidae & $\begin{array}{l}\text { Eucalanus } \\
\text { Rhincalanus }\end{array}$ \\
\hline Megacalanoidea & Megacalanidae & $\begin{array}{l}\text { Calanus } \\
\text { Mesocalanus } \\
\text { Neocalanus } \\
\text { Bathycalanus }\end{array}$ \\
\hline Spinocalanoidea & Spinocalanidae & Spinocalanus \\
\hline
\end{tabular}

(Vinogradov \& Tseitlin 1983, Yamaguchi et al. 2002). While their $\mathrm{C} 1$ through $\mathrm{C} 5$ stages distribute in the epipelagic zone and actively feed on phytoplankton, the late-C5 or C6 individuals descend to the mesopelagic through abyssopelagic zones and are characterized by a non-feeding diapause phase (cf. Ikeda et al. 2004). Because of their wide vertical distribution patterns through the epipelagic and abyssopelagic zones, the Neocalanus spp. were treated separately from other copepods whose habitat depths are more or less limited to narrow depth zones.

Protein (PRO: $\mathrm{mg}$ ind. ${ }^{-1}$ ), RNA:PRO ( $\mu \mathrm{g} \mathrm{mg}^{-1}$ ), PRO:DNA ( $\left.\mathrm{mg} \mathrm{g}^{-1}\right)$ and RNA:DNA $\left(\mu \mathrm{g} \mu \mathrm{g}^{-1}\right)$ data representing single specimens obtained during the same cruise were combined on the basis of same species, stage and sex, and means and standard deviations were computed (Appendix 1). The numbers of datasets were 21 for 20 epipelagic-zone species, 48 for 20 mesopelagic-zone species, 64 for 28 upper bathypelagiczone species, 49 for 35 lower bathypelagic-zone species and 27 for 20 abyssopelagic-zone species
(Appendix 1). Of a total of 80 species, many occurred in 2 or 3 neighboring bathymetric zones, and one (Paraeuchaeta rubra) occurred in the 4 bathymetric zones mesopelagic through abyssopelagic.

The data from various cruises were pooled and then grouped into the 5 sampling zones, 4 developmentalstage/sex categories (C4, C5, and C6 females and C6 males; the single datum for Paraeuchaeta rubra C3 was omitted), 3 feeding types as judged by morphology (carnivore, detritivore and suspension feeder, cf. Yamaguchi et al. 2002), and 2 reaction-speed groups (fast and slow reacting species) based on phylogenyrelated presence/absence of myelinated sheathes enveloping axons. According to Lenz et al. (2000), all species belonging to the Superfamilies Arietelloidea and Centropagoidea lack a myelinated sheath enveloping the axons. The depth of occurrence of the copepods was represented by the mid-point of the sampling intervals, specifically $250 \mathrm{~m}$ for the epipelagic zone, $750 \mathrm{~m}$ for the mesopelagic zone, $1500 \mathrm{~m}$ for the upper bathypelagic zone, $2500 \mathrm{~m}$ for the lower bathypelagic zone and $4000 \mathrm{~m}$ for the abyssopelagic zone. Preliminary plots of RNA:DNA data showed apparent deviation from the normal distribution (skewed to the left), so the data were transformed to natural logarithms (base e) prior to the analysis (Fig. 2).

\section{Protein}

Mean protein contents ( $\mathrm{PRO}, \mathrm{mg}$ ind $\mathrm{.}^{-1}$ ) ranged from 0.18 to 0.47 among the 5 depth-zone groups, from 0.14 to 0.33 among the 4 stage/sex categories (C4, C5, C6F and $\mathrm{C} 6 \mathrm{M}$ ), from 0.21 to 0.37 among the 3 feeding types (carnivore, detritivore and suspension feeder) and from 0.17 to 0.33 between copepods with/without myelin sheathes (Table 2). Variations in mean PRO of copepods grouped by the 4 criteria were significant (1-way ANOVA, p < 0.002). Within each designated group, significantly greater means were found for copepods taken from the upper bathypelagic zone, for $\mathrm{C} 5$ and $\mathrm{C} 6 \mathrm{~F}$ stages, for carnivores, and for the fastreacting group with myelin sheathed axons (Bonferroni test for between means, $p<0.05$ ).

\section{RNA:DNA ratios (excluding Neocalanus spp.)}

Among the 5 depth-zone groups in which RNA:DNA ratios varied from 0.86 to 2.65 , the epipelagic-zone group exhibited a greater ratio than did the other 4 depth-zone groups (1-way ANOVA, and post-hoc Bonferroni test, $\mathrm{p}<0.001)$. With regard to developmental-stage/sex categories, the ratio was the greatest for $\mathrm{C} 6 \mathrm{~F}$, followed by C5, C4 and C6M (Bonferroni test, 

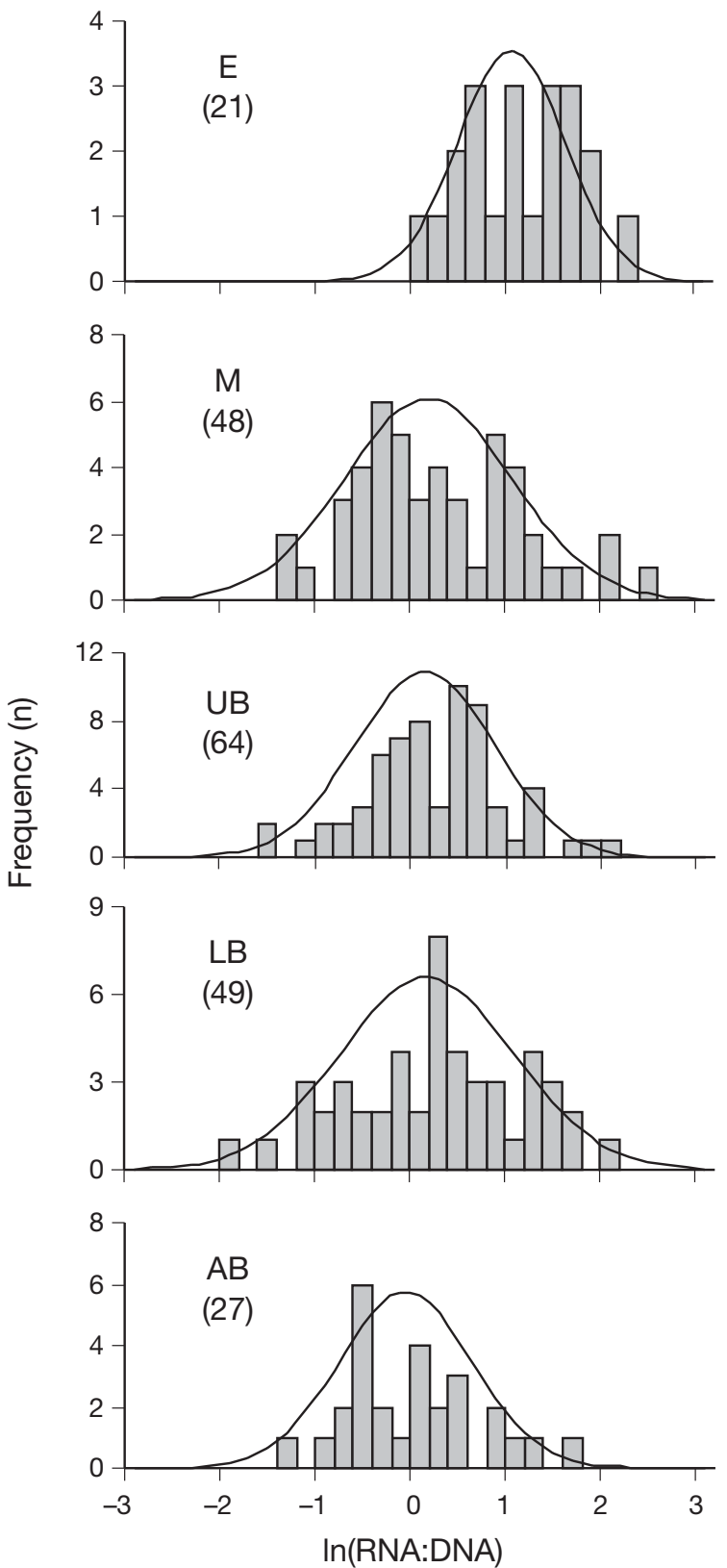

Fig. 2. Log-transformed RNA:DNA ratios of copepods (see Table 2 for depth-zone abbreviations) in the North Pacific. Values in parentheses: number of datasets. Normalized data were used for the calculation of means, SDs and statistical comparisons (see Tables $2 \& 3$ )

$\mathrm{p}<0.001)$. Lower RNA:DNA ratios were seen in carnivores among the 3 feeding types, and in those with myelin sheathes between the 2 reaction-speed groups (Bonferroni test, $\mathrm{p}<0.001$ ).

Designating the depth of occurrence, stage/sex, feeding type, presence/absence of myelinated sheath and protein content as independent variables, the relationships of these variables to each dependent variable ( $Y: \ln [\mathrm{RNA}: D N A])$ of copepods from the epipelagic
Table 2. Summary of protein (PRO) and RNA:DNA data of copepods in Appendix 1 (available at www.int-res.com/ articles/suppl/b001p099_app.pdf) grouped into 5 depth zones (E: epipelagic, M: mesopelagic, UB: upper bathypelagic, LB: lower bathypelagic, AB: abyssopelagic), 4 development/sex categories, 3 feeding types and 2 presence/absence types of myelinated sheath enveloping axons. Differences among groups were tested by 1-way ANOVA, combined with Bonferroni test for between means. Mean and SD range based on log-transformed data

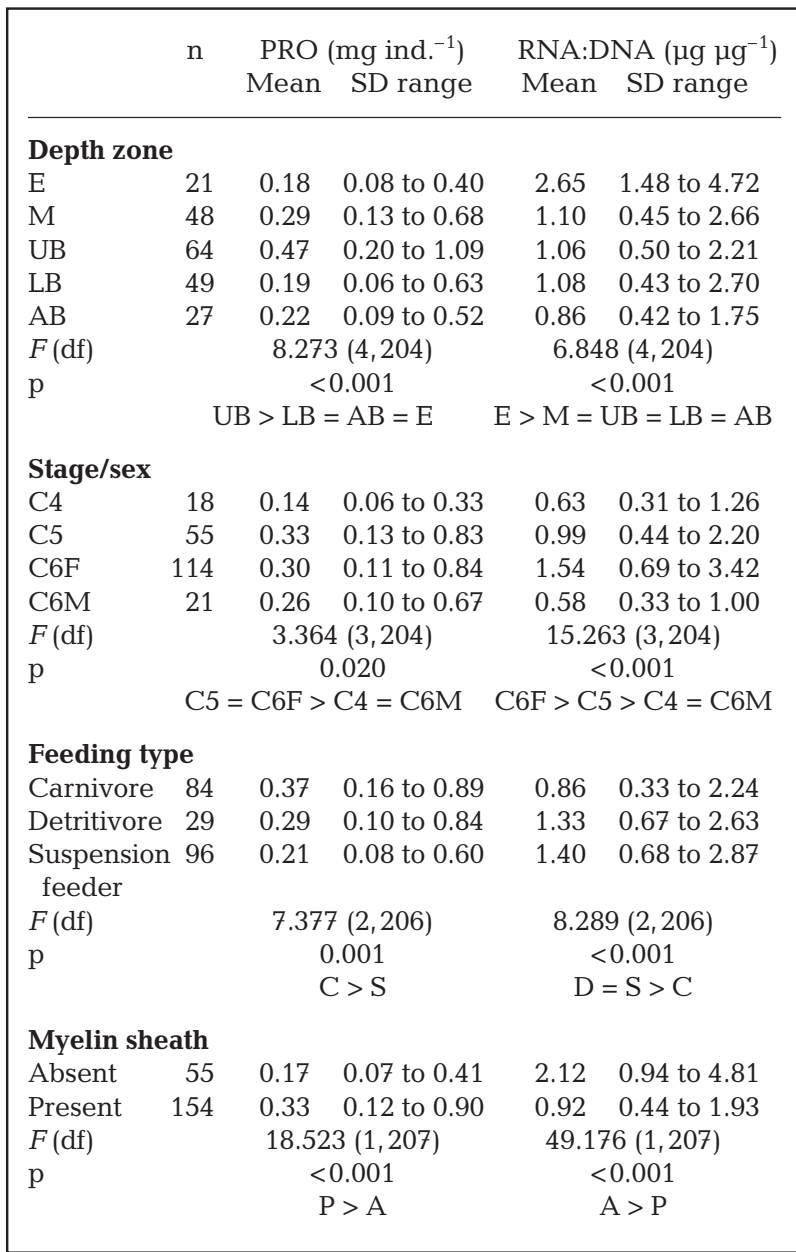

through abyssopelagic zones (Table 2) were analyzed by a stepwise multiple regression method (Sokal \& Rohlf 1995). The full multiple regression model adopted was:

$$
\begin{gathered}
Y=\mathrm{UB}+\mathrm{LB}+\mathrm{AB}+\mathrm{C} 5+\mathrm{C} 6 \mathrm{~F}+\mathrm{C} 6 \mathrm{M}+\mathrm{DETR}+\mathrm{SUS}+ \\
\mathrm{MYEL}+\ln \mathrm{PRO}+\text { constant }
\end{gathered}
$$

where $\mathrm{UB}, \mathrm{LB}$ and $\mathrm{AB}$ are dummy variables representing depth; C5, C6F, C6M represent stage; DETR and SUS represent feeding type. Definitions of these dummy variables are as in Ikeda et al. (2006b). The dummy variable MYEL was defined as 1 when myelinated sheath is present, and 0 when it is absent. The independent variable lnPRO was the value of the loga- 
rithm (base e) of PRO (mg ind. ${ }^{-1}$ ), which is the index of the body mass. Predictor variables are added if $\mathrm{p} \leq 0.05$ and removed if $p \geq 0.10$. The calculation was conducted using SPSS version 11.5.

Among 11 independent variables tested, $\ln [\mathrm{RNA}$ : DNA] was attributed positively by feeding types (detritivore and suspension feeder) but negatively by a category of developmental-stage/sex (C6M) (Table 3). The effects of the depth of occurrence were also significant and either positive (epipelagic) or negative (abyssopelagic). Overall, the regression analysis yielded similar results to those of 1-way ANOVA (Table 2) in which

Table 3. Attributes of the depth (E, UB, LB or AB: see Table 2 for definitions), stage/sex (C5, C6F or C6M), feeding type (DETR: detritus or SUS: suspension), presence/absence of myelinated axons (MYEL) and lnPRO to lnRNA:DNA of epipelagic through abyssopelagic copepods. +++, ++ and +: coefficients are all positive and significant at $\mathrm{p}<0.001, \mathrm{p}<0.01$ and $\mathrm{p}<0.05$, respectively. ,----- and - : coefficients are all negative and significant at $\mathrm{p}<0.001, \mathrm{p}<0.01$ and $\mathrm{p}<0.05$, respectively; ns: not significant. See 'RNA:DNA ratios (excluding Neocalanus spp.)' for details

Independent $\mathrm{E} \quad \mathrm{UB}$ LB AB C5 C6F C6M DETR SUS MYEL InPRO variable

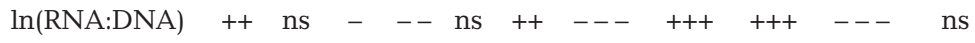

Table 4. Neocalanus spp. Summary of protein (PRO) and RNA:DNA data of 3 copepods (Cris: $N$. cristatus; Plum: $N$. plumchrus; Flem: N. flemingeri) (see Table 2

for depth-zone abbreviations). Means and SD based on log-transformed data

\begin{tabular}{|c|c|c|c|c|c|c|c|}
\hline \multirow[t]{2}{*}{ Species } & \multirow{2}{*}{$\begin{array}{l}\text { Stage/ } \\
\text { sex }\end{array}$} & \multirow{2}{*}{$\begin{array}{l}\text { Depth } \\
\text { zone }\end{array}$} & \multirow[t]{2}{*}{$\mathrm{n}$} & \multicolumn{2}{|c|}{ PRO (mg ind.$^{-1}$ ) } & \multicolumn{2}{|c|}{ RNA:DNA $\left(\mathrm{mg} \mathrm{mg}^{-1}\right)$} \\
\hline & & & & Mean & SD range & Mean & SD range \\
\hline \multirow[t]{3}{*}{ Cris } & C5 & E-LB & 22 & 1.02 & 0.58 to 1.82 & 2.05 & 1.22 to 3.43 \\
\hline & $\mathrm{C} 6 \mathrm{~F}$ & $\mathrm{M}-\mathrm{AB}$ & 16 & 0.64 & 0.28 to 1.49 & 2.63 & 1.42 to 4.87 \\
\hline & $\mathrm{C} 6 \mathrm{M}$ & M-LB & 7 & 1.41 & 0.85 to 2.37 & 1.26 & 0.60 to 2.65 \\
\hline \multirow[t]{3}{*}{ Plum } & C5 & E-LB & 29 & 0.17 & 0.09 to 0.29 & 3.02 & 1.70 to 5.38 \\
\hline & $\mathrm{C} 6 \mathrm{~F}$ & M-LB & 30 & 0.12 & 0.06 to 0.24 & 4.60 & 2.70 to 7.83 \\
\hline & $\mathrm{C} 6 \mathrm{M}$ & UB-LB & 12 & 0.19 & 0.14 to 0.25 & 1.19 & 0.55 to 2.58 \\
\hline \multirow[t]{3}{*}{ Flem } & C5 & $\mathrm{AB}$ & 1 & 0.22 & & 1.75 & \\
\hline & $\mathrm{C} 6 \mathrm{~F}$ & $\mathrm{M}-\mathrm{AB}$ & 12 & 0.27 & 0.18 to 0.41 & 3.97 & 1.91 to 8.27 \\
\hline & C6M & $\mathrm{AB}$ & 1 & 0.26 & & 1.30 & \\
\hline
\end{tabular}

RNA:DNA ratios of Neocalanus spp.

Compared with Neocalanus cristatus and N. plumchrus, the data on $N$. flemingeri was largely limited to C6F and only a single datum was available for each of C5 and C6M stages (Tables 4 \& 5). Prior to the analysis, the data for C5 specimens of $N$. cristatus and $N$. plumchrus from the epipelagic zone (non-diapausing) and mesopelagic or much deeper zones (diapausing) were compared. There were no significant differences in RNA:DNA ratios between diapausing and non-diapausing specimens (respective ratios, $\pm \mathrm{SD}$, are $2.3 \pm 1.3[\mathrm{~N}=16]$ and $2.3 \pm 1.1[\mathrm{~N}=6]$ for $N$. cristatus, and $3.6 \pm 2.0[\mathrm{~N}=22]$ and $3.5 \pm 2.2[\mathrm{~N}=7]$ for $N$. plumchrus; Mann-Whitney $U$-test at $\mathrm{p}>0.05$ for both species). Using these results, the C5 data of both species from the epipelagic and mesopelagic or much deeper zones were pooled to facilitate within-species (stage/sex) and between-species analyses of each variable (Table 4).

For between-stage/sex difference, $\mathrm{PRO}$ of C6M was greater than that of C6F in Neocalanus cristatus, but the betweensex difference in PRO was not significant for C6 $N$. plumchrus. Both species showed similar RNA:DNA ratios: the greatest and least ratios were seen in C6F and C6M, respectively (Bonferroni test, $\mathrm{p}<0.05)$. Regarding C5, C6F or C6M of the 3 Neocalanus spp., N. cris-

Table 5. Neocalanus spp. Protein (PRO) and RNA:DNA data. Differences within and between species tested by 1-way ANOVA, combined with Bonferroni test (Test) for between means. Means and SD based on log-transformed data. ${ }^{\text {NS }}$ : not significant ( $p>0.05$ ); Cris: N. cristatus; Plum: N. plumchrus; Flem: N. flemingeri. Only a single datum was available for N. flemingeri C5 and C6M stages

\begin{tabular}{|c|c|c|c|c|c|c|c|}
\hline & \multirow[t]{2}{*}{ df } & \multicolumn{3}{|c|}{ PRO } & \multicolumn{3}{|c|}{ - RNA:DNA } \\
\hline & & $F$ & $\mathrm{p}$ & Test & $F$ & $\mathrm{p}$ & Test \\
\hline \multicolumn{8}{|c|}{ Between stage/sex } \\
\hline Cris & 2,42 & 3.963 & 0.027 & $\mathrm{C} 6 \mathrm{M}>\mathrm{C} 6 \mathrm{~F}$ & 3.768 & 0.031 & $\mathrm{C} 6 \mathrm{~F}>\mathrm{C} 6 \mathrm{M}$ \\
\hline Plum & 2,68 & 3.165 & 0.048 & & 22.085 & $<0.001$ & $\mathrm{C} 6 \mathrm{~F}>\mathrm{C} 5>\mathrm{C} 6 \mathrm{M}$ \\
\hline \multicolumn{8}{|c|}{ Between species } \\
\hline C5 & 1,49 & 127.157 & $<0.001$ & Cris $>$ Plum & 6.172 & 0.016 & Plum $>$ Cris \\
\hline $\mathrm{C} 6 \mathrm{~F}$ & 2,55 & 31.161 & $<0.001$ & Cris $>$ Flem $>$ Plum & 4.537 & 0.015 & Plum $>$ Flem $=$ Cris \\
\hline $\mathrm{C} 6 \mathrm{M}$ & 1,17 & 128.708 & $<0.001$ & Cris $>$ Plum & 0.029 & $0.867^{\mathrm{NS}}$ & \\
\hline
\end{tabular}


tatus showed the greatest PRO values. Among C6F specimens, $N$. plumchrus showed greater RNA:DNA ratios than did the other species (1-way ANOVA, $\mathrm{p}<0.02$ and Bonferroni test, $\mathrm{p}<0.05)$. When compared to C5 N. cristatus, C5 N. plumchrus showed greater RNA:DNA ratios (1-way ANOVA, p < 0.02).

Comparison of C6M and C6F data of Neocalanus spp. with other copepods occurring from the mesopelagic through abyssopelagic may be not meaningful because of the non-feeding condition of C6M and C6F. The pooled C5 data of both N. cristatus and N. plumchrus from the epipelagic though abyssopelagic zones were nearly comparable to those from the epipelagic zone only, but significantly higher than those from the mesopelagic through the abyssopelagic zones (1-way ANOVA, Bonferroni test at $\mathrm{p}=0.05$ ).

\section{DISCUSSION}

\section{Parameters affecting nucleic acid ratios}

Among the parameters affecting RNA:DNA ratios examined in this study (developmental-stage/sex, feeding type, reaction-speed type and protein [= body mass], cf. Table 3), the changes with development have been reported in Calanus pacificus (Ota \& Landry 1984) and C. finmarchicus (Wagner et al. 1998, 2001), both raised in the laboratory. According to these authors, RNA:DNA ratios in C. finmarchicus increased progressively during development (maximum value $=8$ ). In contrast to $C$. finmarchicus, the results for C. pacificus were more variable, but the developmental increase in RNA:DNA ratios was still apparent. No information is available for C6 males in these 2 studies. While the developmentalstage/sex in analysis on mixed copepods from the epipelagic through abyssopelagic zones (Table 4) was limited to C4, C5 and C6 males and C6 females, resultant developmental patterns in RNA:DNA ratios were identical to that of $C$. finmarchisus. Development/sex patterns of RNA:DNA of C5 and C6 female Neocalanus spp. observed in this study (Table 4) are also similar to those of C. finmarchicus. Higher RNA:DNA ratios in C6 female copepods could be attributed to matured eggs in the body, which is supported by the close association of higher RNA:DNA ratios with higher daily egg production rates in Paracalanus sp. (Nakata et al. 1994), Acartia grani (Saiz et al. 1998) and A. bifilosa (Gorokhova 2003). In contrast, lower RNA:DNA ratios seen for C6 males of mixed copepods (Table 2) and Neocalanus spp. (Table 4) are indicative of no substantial increase in RNA relative to DNA during the gonad maturation process in males. Male C6 of many copepods, including Euchaeta, Euchirella, Gaetanus, Paraeuchaeta, Neocalanus spp. etc. have reduced oral appendages and do not feed (cf. Mauchline 1998). But it appears that this is not the cause for the observed low RNA:DNA ratios, as non-feeding C6 females of Neocalanus spp. exhibit high ratios (2.6 to 4.6 , Table 4 ).

Wagner et al. (1998) noted significantly lower RNA:DNA ratios of C5 Calanus funmarchicus in diapause ( 1 as compared with 2 to 3 in non-diapausing specimens). However, C5 specimens of Neocalanus cristatus and $N$. plumchrus from $<500 \mathrm{~m}$ depth (before entering diapause) and $>500 \mathrm{~m}$ depth (in diapause) did not show significant differences in RNA:DNA ratios in this study, with mean values of 2.3 for $<500 \mathrm{~m}$ and 3.5 for $>500 \mathrm{~m}$ (see 'Results').

Among the 3 feeding types, carnivores showed consistently lower RNA:DNA ratios (Table 2), which imply their lower protein synthetic activities relative to suspension feeders and detritivores. Among the 3 feeding types, deeper-living carnivorous copepods also exhibited the lowest metabolism and lowest body $\mathrm{N}$ content in our previous analyses (Ikeda et al. 2006a,b), suggesting their 'ambush' feeding in contrast to active 'cruising' feeding in well-illuminated epipelagic zones as has been well documented in mid-water fishes (Miller 2004). Considering that prey zooplankton biomass decreases rapidly toward greater depths (Vinogradov 1968, Vinogradov \& Tseitlin 1983), it appears that carnivorous feeding is not well adapted to deepsea environments in comparison to suspension or detritivorous feeding. In fact, the proportion of carnivores in zooplankton communities increases from the surface to around $2000 \mathrm{~m}$, then decreases rapidly toward $6000 \mathrm{~m}$ in the western subarctic Pacific (Vinogradov \& Tseitlin 1983).

The presence of myelinated sheath (MYEL) was found to be the another parameter affecting RNA:DNA ratios of the copepods negatively (Table 2). Typically, copepod Families including Metridinidae, Acartiidae, Candaciidae, Pontellidae and Temoridae lack MYEL (e.g. slow response) and those including Calanidae, Paracalanidae, Eucalanidae, Clausocalanidae and Eucalanidae have MYEL (e.g. fast response) (Lenz et al. 2000). The negative effect of MYEL presence on RNA:DNA ratios suggests lower protein synthetic activities for copepods with MYELs, as compared to those without MYELs and slow escape reactions. In our previous studies, copepods with MYEL have been shown to have higher metabolic rates (Ikeda et al. 2006a) and higher $\mathrm{C}$ and $\mathrm{N}$ contents in the body (Ikeda et al. 2006b). These results may imply that copepods with MYEL are characterized by a lower protein growth/ metabolism efficiency while achieving a larger deposition of organic matter; however full evaluation of phylogenetic patterns in energy/material budgets in copepods will not be possible until sufficient physiological data are available. 


\section{Habitat depth vs. RNA:DNA ratio}

The primary food source for deep-sea pelagic organisms is the photosynthetic products from the top of the water column, which are passively transported to depth as sinking detritus and feces of zooplankton, or actively transported by vertically migrating zooplankters (cf. Vinogradov \& Tseitlin 1983). Gut content analyses of copepods from mesopelagic and bathypelagic zones have revealed that diatoms, protozoans, detritus, feces and carcasses were major components, along with many unidentifiable materials (Harding 1974, Kosobokova et al. 2002). Thus, an immediate explanation for the lower RNA:DNA ratios of deeper-living copepods of this study may be slower protein growth caused by limited food supply to the deep sea. Reduction of food supply with depth has been given as a cause for the rapid decline in zooplankton/micronekton biomass with increasing depth across world oceans (e.g. Vinogradov 1968, Vinogradov \& Tseitlin 1983, Childress 1995); however, limitation of food supply is not thought to influence the physiology of individuals (but see Childress 1995). In other words, the organisms that were found in food-limited environments such as the deep sea cannot, themselves, be food limited (Seibel \& Drazen 2007).

As an alternative explanation, the decrease in water temperature downward in the North Pacific (epipelagic zone: 3 to $20^{\circ} \mathrm{C}$, mesopelagic through abyssopelagic zones: 1.5 to $3^{\circ} \mathrm{C}$; Favorite et al. 1976) may affect RNA:DNA ratios of pelagic copepods, since temperature is already known to be one of important parameters in growth of epipelagic copepods (global growth model; Hirst \& Bunker 2003). Our data on RNA: DNA ratios from the epipelagic zone of the North Pacific Ocean (Fig. 1) were divided into regions north (cold regime) and south (warm regime) of the Subarctic Boundary $\left(\sim 40^{\circ} \mathrm{N}\right.$; Favorite et al. 1976) to examine the temperature effect. This north-to-south comparison showed that the mean RNA:DNA ratios $(3.1 \pm 2.1 \mathrm{SD}$ vs. $2.8 \pm 1.3$, both $\mathrm{N}=11$ ) were not significantly different (Mann-Whitney $U$-test, $\mathrm{p}>0.11$ ). In laboratory experiments, RNA:DNA ratios of Calanus pacificus raised at 3 temperatures ranging from 8 to $15^{\circ} \mathrm{C}$ (Ota \& Landry 1984), C. finmarchicus at 3 temperatures ranging from 4 to $12^{\circ} \mathrm{C}$ (Wagner et al. 2001) and Acartia bifilosa at 9 and $16^{\circ} \mathrm{C}$ (Gorokhova 2003) all showed no decrease, or slight decrease at higher temperatures. The same results (no or slight decrease in the ratios due to temperature increases) have been reported on the larvae of caregonid fish raised at 2 temperatures in the laboratory (Malzahn et al. 2003). While the global pattern of RNA:DNA ratios of pelagic copepods is not known as yet, circumstantial evidence presently available indicates that the depth-related pattern of the RNA:DNA ratios revealed in this study (i.e. a reduction of the ratios with depth) is opposite to that expected (stable ratios, or increase, with depth). Thus, the water temperature gradient toward greater depths in the North Pacific does not explain the depth-related pattern of RNA:DNA ratios of pelagic copepods observed in this study. It should be noted that the conclusions mentioned above regarding the decline in metabolic rates (Ikeda et al. 2006a) and body $\mathrm{N}$ content (Ikeda et al. 2006b) of calanoid copepods with depth are free from the effects of vertical temperature gradients, as the epipelagic data compared in the aforementioned studies were from similar thermal regimes, e.g. Antarctic/Arctic waters.

As a habitat for pelagic animals, the deep sea is dark, since sunlight only penetrates the upper $1000 \mathrm{~m}$ of the ocean (Warrant \& Locket 2004). For pelagic animals with developed vision (i.e. eyes), a rapid decline in metabolic rates has been observed with depth, and a 'visual interactions' hypothesis has been proposed to explain the phenomenon (Childress 1995). According to this hypothesis, vision-aided reaction distance in prey-predator relationships shortens downward due to diminishing light, thus requiring progressively less energy expenditure for the reactions with increasing depth. This explanation is also supported by the observations that protein (= muscle) concentration in the body declines in deeper-living micronektonic fishes and crustaceans (Childress \& Nygaard 1973, 1974). For pelagic animals lacking visual perception systems, such as the calanoid copepods of this study, the visual interactions hypothesis predicts that the range of reaction should not change with increasing habitat depths, and thus neither their metabolic rates nor protein concentrations should be affected by depth. Contrary to that prediction, Ikeda et al. (2006a) indicated that the respiration rates (normalized by temperature and body mass) of copepods decreased by about $30 \%$ between the epipelagic and upper-bathypelagic zones, and interpreted this as a result of reduction in predation pressure ('predation-mediated selection' hypothesis Ikeda et al. 2006a). Furthermore, Ikeda et al. (2006b) showed that $\mathrm{N}$ content of dried calanoid copepods declines with increased depth, as was observed for micronektonic fishes and crustaceans by Childress \& Nygaard (1973, 1974).

Depth-related declining patterns in RNA:DNA ratios (this study), metabolism (= oxygen consumption, Ikeda et al. 2006a) and body $\mathrm{N}$ composition (Ikeda et al. $2006 a, b)$ of pelagic copepods in the North Pacific are shown in Fig. 3, in which the original epipelagic data (those of Arctic/Antarctic copepods) were replaced with those of copepods living in the epipelagic North Pacific and determined at near in situ temperatures (mean: $\sim 11^{\circ} \mathrm{C}$ ). While protein synthetic activities (= RNA:DNA ratios) have not been discussed, and are not directly re- 


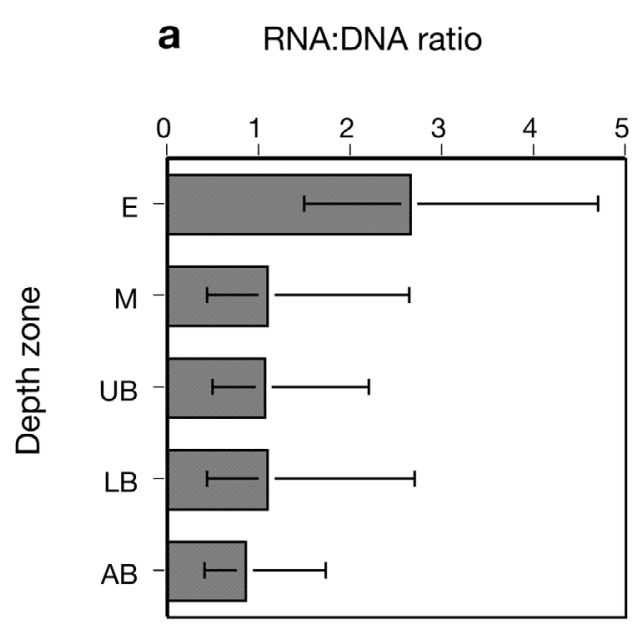

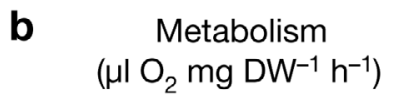

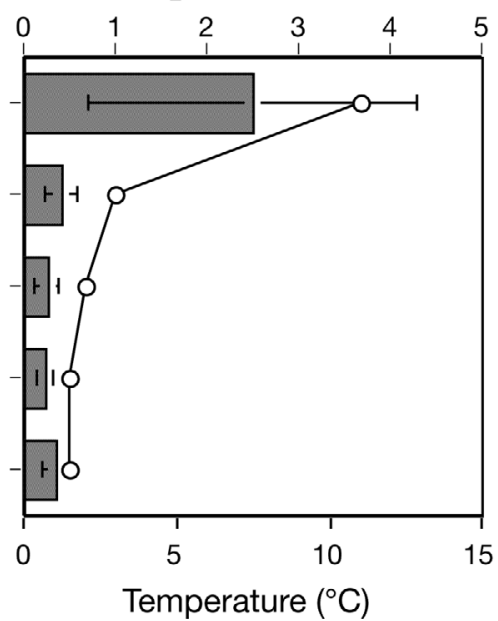

C

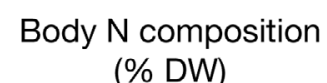
(\% DW)

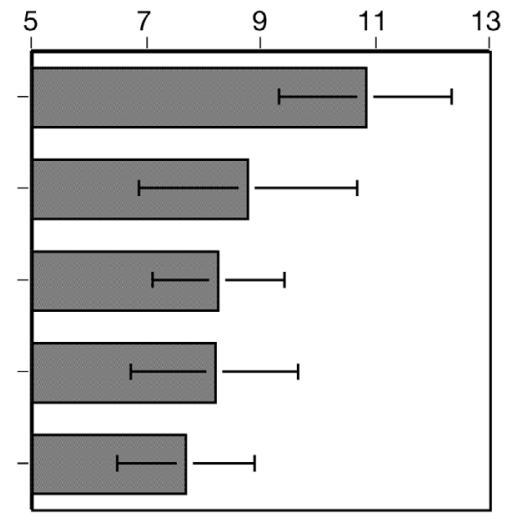

Fig. 3. Depth-related decline in (a) RNA:DNA ratios (this study), (b) metabolism (bar) vs. temperature (O) (Ikeda et al. 2006a), and (c) body $\mathrm{N}$ content (Ikeda et al. 2006b) of pelagic copepods (see Table 2 for depth-zone abbreviations) in the North Pacific. Data are means $( \pm \mathrm{SD})$. To make direct comparison with RNA:DNA ratios of this study possible, we replaced metabolism and body $\mathrm{N}$ content data of epipelagic copepods from Ikeda et al. (2006a,b) (Arctic/Antarctic copepods) with those of epipelagic copepods in the North Pacific (i.e. data from the appendix of Ikeda et al. 2007); this change did not alter the overall depth-related reduction patterns of metabolism and body $\mathrm{N}$ content appreciably. The temperature of each depth zone was represented by those adopted as in situ temperatures for respiration (metabolism) experiments (cf. Ikeda et al. 2007)

lated to the origin of the 2 hypotheses mentioned above, lower RNA:DNA ratios of deeper-living copepods observed in this study (Table 4) are in line with their lower metabolic rates observed by Ikeda et al. (2006a) (Fig. 3). For this reason, protein synthesis has been evaluated to require the highest energy demand among the processes involved in the formation of new body mass in copepods (Kiørboe et al. 1985, Thor 2000). Reduced protein synthetic activities of deep-sea copepods may reflect the gradual decrease in body $\mathrm{N}$ downward among pelagic copepods from the epipelagic through the abyssopelagic zones in the subarctic Pacific (Ikeda et al. 2006b). All these results strongly suggest that the life of deep-sea copepods is 'slow' as compared to that of shallow living ones. Apparently, interzonal copepods such as Neocalanus spp. collected from depth are an exception, and their RNA:DNA ratios were found to be almost equivalent to those of epipelagic-zone species. Despite their deep occurrence, ratios as high as the epipelagic species suggest that the ratios reflect the epipelagic zone at where the copepods achieve rapid development and large lipid deposition prior to the completion of their life cycle at depth (cf. Ikeda et al. 2004). Judging by sampling season (i.e. July, see Appendix 1), the highest RNA:DNA ratios in $N$. plumchrus among Neocalanus spp. may be due to its delayed development in the shallow layer of the western subarctic Pacific as compared to $N$. cristatus and $N$. flemingeri (Kobari \& Ikeda 2000)
In conclusion, the present study revealed that protein synthetic activities, as judged by RNA:DNA ratios of copepods living in the epipelagic through abyssopelagic zones in the North Pacific, decline toward greater depths, though developmental-stage/ sex, feeding types or phylogeny-related presence or absence of MYEL could also affect the ratios simultaneously. We favor the 'predation-mediated selection' hypothesis to describe the prime cause for this depthrelated decline in RNA:DNA ratios in pelagic copepods, rather than limited food supply or low deep-sea temperature.

Acknowledgements. We are grateful to C. B. Miller for reviewing earlier drafts of this paper; his constructive comments significantly improved the manuscript. This study was partly supported by grant JSPS KAKENSHI 14209001 to T.I.

\section{LITERATURE CITED}

Båmstedt U (1983) RNA concentration in zooplankton: seasonal variation in boreal species. Mar Ecol Prog Ser 11:291-297

Båmstedt U, Skjoldal HR (1980) RNA concentration of zooplankton: relationship with size and growth. Limnol Oceanogr 25:304-316

Bentle LA, Dutta S, Metcoff J (1981) The sequential enzymatic determination of DNA and RNA. Anal Biochem 116:5-16

Buitenhuis E, Quéré CL, Aumont $\mathrm{O}$, Beaugrand $\mathrm{G}$ and others (2006) Biogeochemical fluxes through mesozooplankton. Global Biogeochem Cycles 20:GB2003, doi:10.1029/ 2005GB002511

Caldarone EM, Wagner M, Onge-Burnes JS, Buckley LJ (2001) 
Protocol and guide for estimating nucleic acids in larval fish using a fluorescence microplate reader. Ref Doc 01-11, Northeast Fisheries Science Center, Woods Hole, MA

Canino MF, Caldarone EM (1995) Modification and comparison of two fluorometric techniques for determining nucleic acid contents of fish larvae. Fish Bull US Dep Comm 93: 158-165

Childress JJ (1995) Are there physiological and biochemical adaptations of metabolism in seep-sea animals? Trends Ecol Evol 10:30-36

Childress JJ, Nygaard M (1973) The chemical composition of midwater fishes as a function of depth of occurrence off southern California. Deep-Sea Res 20:1093-1109

Childress JJ, Nygaard M (1974) Chemical composition and buoyancy of midwater crustaceans as a function of depth of occurrence off Southern California. Mar Biol 27: $225-238$

Clarke A, Rodhouse PG, Holmes LJ, Pascoe PL (1989) Growth rate and nucleic acid ratio in cultured cuttlefish, Sepia officinalis (Mollusca: Cephalopoda). J Exp Mar Biol Ecol 133: 229-240

Dagg MJ, Littlepage JL (1972) Relationships between growth rate and RNA, DNA, protein and dry weight in Artemia salina and Euchaeta elongata. Mar Biol 17:162-170

Favorite F, Dodimead AJ, Nasu K (1976) Oceanography of the subarctic Pacific region, 1960-1971. Bull Int North Pacific Fish Comm 33:1-187

Gorokhova E (2003) Relationship between nucleic acid levels and egg production rates in Acartia bifilosa: implications for growth assessment of copepods in situ. Mar Ecol Prog Ser 262:163-172

Gorokhova E, Kyle M (2002) Analysis of nucleic acids in Daphinia: development of methods and ontogenetic variations in RNA-DNA content. J Plankton Res 24:511-522

Harding GCH (1974) The food of deep-sea copepods. J Mar Biol Assoc UK 54:141-155

Hernández-León S, Ikeda T (2005) A global assessment of mesozooplankton respiration in the ocean. J Plankton Res 27:153-158

Hirst AG, Bunker AJ (2003) Growth of marine planktonic copepods: Global rates and patterns in relation to chlorophyll $a$, temperature, and body weight. Limnol Oceanogr 48: $1988-2010$

Hirst AG, Kiørboe T (2002) Mortality of marine planktonic copepods: global rates and patterns. Mar Ecol Prog Ser 230: 195-209

Ikeda T, Kanno Y, Ozaki K, Shinada A (2001) Metabolic rates of epipelagic marine copepods as a function of body mass and temperature. Mar Biol 139:587-596

Ikeda T, Sano F, Yamaguchi A (2004) Metabolism and body composition of a copepod Neocalanus cristatus (Crustacea) from the bathypelagic zone of the Oyashio region, western subarctic Pacific. Mar Biol 145:1181-1190

Ikeda T, Sano F, Yamaguchi A, Matsuishi T (2006a) Metabolism of mesopelagic and bathypelagic copepods in the western North Pacific Ocean. Mar Ecol Prog Ser 322:199-211

Ikeda T, Yamaguchi A, Matsuishi T (2006b) Chemical composition and energy content of deep-sea calanoid copepods in the western North Pacific Ocean. Deep-Sea Res I 53: 1791-1809

Ikeda T, Sano F, Yamaguchi A (2007) Respiration in marine pelagic copepods: a global-bathymetric model. Mar Ecol Prog Ser 339:215-219

Kawamura A (1968) Performance of Peterson type closing net.
Bull Plankton Soc Jpn 15:11-12

Kiørboe T, Møhlenberg F, Hamburger K (1985) Bioenergetics of the planktonic copepod Acartia tonsa: relation between feeding, egg production and respiration, and composition of specific dynamic action. Mar Ecol Prog Ser 26:85-97

Kobari T, Ikeda T (2000) Life cycle of Neocalanus species in the Oyashio region. Bull Plankton Soc Jpn 47:129-135

Kosobokova KN, Hirshe HJ, Scherzinger T (2002) Feeding ecology of Spinocalanus antarcticus, a mesopelagic copepod with a looped gut. Mar Biol 141:503-511

Lenz PH, Hartline DK, Davis AD (2000) The need for speed. I. Fast reactions and myelinated axons in copepods. J Comp Physiol A 186:337-345

Lowry OH, Rosebrough NJ, Farr AL, Randall RJ (1951) Protein measurement with the Folin Phenol reagent. J Biol Chem 193:265-275

Malzahn AM, Clemmesen C, Rosenthal H (2003) Temperature effects on growth and nucleic acids in laboratory-reared larval coregonid fish. Mar Ecol Prog Ser 259:285-293

Mauchline J (1998) The biology of calanoid copepods. Adv Mar Biol 33:1-710

Miller CB (2004) Biological oceanography. Blackwell, Oxford

Nakata K, Nakno H, Kikuchi H (1994) Relationship between egg productivity and RNA/DNA ratio in Paracalanus sp. in the frontal waters of the Kuroshio. Mar Biol 119: 591-596

Ota AY, Landry MR (1984) Nucleic acids as growth rate indicators for early developmental stages of Calanus pacificus Brodsky. J Exp Mar Biol Ecol 80:147-160

Saiz E, Calbet A, Fara A, Berdalet E (1998) RNA content of copepods as a tool for determining adult growth rates in the field. Limnol Oceanogr 43:465-470

Seibel BA, Drazen JC (2007) The rate of metabolism in marine animals: environmental constraints, ecological demands and energetic opportunities. Phil Trans R Soc Lond B 362: 1-18, doi:10.1098/rstb.2007.2101

Shin HC, Nicol S, King RA (2003) Nucleic acid content as a potential growth rate estimator of antarctic krill: results from field-caught krill from the Indian sector of the Southern Ocean. Mar Freshw Behav Physiol 36:295-305

Sokal RR, Rohlf FJ (1995) Biometry. The principles and practice of statistics in biological research. Freeman, New York

Thor P (2000) Relationship between specific dynamic action and protein deposition in calanoid copepods. J Exp Mar Biol Ecol 245:171-182

Vinogradov ME (1968) Vertical distibution of oceanic zooplankton. Israel Program for Scientific Translations, Jerusalem

Vinogradov ME, Tseitlin VB (1983) Deep-sea pelagic domain (aspects of bioenergetics). In: Rowe GT (ed) The sea, Vol 8: Deep-sea biology. John Wiley \& Sons, New York, p 123-165

Wagner M, Durbin E, Buckley L (1998) RNA:DNA ratios as indicators of nutritional condition in the copepod Calanus finmarchicus. Mar Ecol Prog Ser 162:173-181

Wagner MM, Campbell RG, Boudreau CA, Durbin EG (2001) Nucleic acids and growth of Calanus finmarchicus in the laboratory under different food and temperature conditions. Mar Ecol Prog Ser 221:185-197

Warrant EJ, Locket NA (2004) Vision in the deep sea. Biol Rev Camb Phil Soc 79:671-712

Yamaguchi A, Watanabe $\mathrm{Y}$, Ishida $\mathrm{H}$, Harimoto $\mathrm{T}$ and others (2002) Community and trophic structures of pelagic copepods down to greater depths in the western subarctic Pacific (WEST-COSMIC). Deep-Sea Res I 49:1007-1025 